\title{
Criminal Justice for Assaulted Women in Sweden - Law versus Practice
}

\author{
Maria Scheffer Lindgren (Correspondent author) \\ Faculty of Social and Life Sciences, Karlstad University \\ SE-651 88 Karlstad, Sweden \\ Tel: 46-54-180-131Ｅ-mail: maria.scheffer.lindgren@gmail.com \\ Barbro Renck \\ Faculty of Social and Life Sciences, Karlstad University \\ SE-651 88 Karlstad, Sweden \\ E-mail: barbro.renck@kau.se \\ Christian Diesen \\ Department of law, Stockholm University \\ SE-106 91 Stockholm, Sweden \\ E-mail: christian.diesen@juridicum.su.se
}

$\begin{array}{lc}\text { Received: November 28, } 2011 & \text { Accepted: December 16, } 2011 \quad \text { Published: March 1, } 2012 \\ \text { doi:10.5539/res.v4n1p167 } & \text { URL: http://dx.doi.org/10.5539/res.v4n1p167 }\end{array}$

This study was financially supported by the Crime Victim Compensation and Support Authority in Umea, Sweden, the Swedish police organisation and Karlstad University, Sweden.

\begin{abstract}
This article examines whether there is criminal justice for women in reported cases of intimate partner violence (IPV) in Sweden. A sample of 474 cases drawn from police records show that criminal justice for victims of IPV does not accord with the intentions of the law. Factors that were most likely to increase the probability of the crime report leading to prosecution were whether the suspect had been interrogated and whether the woman was cooperating. IPV crimes have been subject to public prosecution since 1982 in Sweden, which means that legal action can be taken without the women's cooperation, but in most of the cases that still seems to be a requirement for pursuing prosecution and for taking other legal action, such as issuing contact prohibition orders or the provision of injured party counsel. There is a need for greater knowledge of the complexity of IPV, and a greater willingness to take serious measures against these serious crimes.
\end{abstract}

Keywords: Intimate partner violence, IPV, Women, Criminal justice, Prosecution

\section{Introduction}

Violence against women is a human rights problem and a serious crime, but almost universally under-reported (Watts and Zimmerman, 2002). More than twenty-six thousand crimes of men's violence against women are reported each year in Sweden, a country with about 9 million inhabitants. More than 50 per cent of these were committed by an intimate partner. Of these reported cases, an average for the country as a whole of 21 percent resulted in prosecution (BRA, 2008a). However, the Swedish National Council for Crime Prevention estimates the number of unreported cases to be huge, 75-80 percent (BRA, 2008b). A Swedish national survey showed that 67 percent of Swedish women between eighteen and sixty-four had been assaulted by a man some time after the age of fifteen (Lundgren, Heimer, Westerstrand and Kalliokoski, 2001). It is estimated that 1.9 million women 
are physically assaulted each year in the United States, with more than three fourths of those assaults perpetrated by an intimate partner (Tjaden and Thoennes, 2000). British research shows that women have been abused on average thirty times before they get into contact with the police (Laycock, 1997). On the other hand about 25 percent of women reporting a crime, reporting at least one other crime within a year (BRA, 2001).

The World Health Organisation (WHO) defines intimate partner violence (IPV) as all kinds of behaviour that results in sexual, physical or psychological harm to women in heterosexual relationships and as a global public health and gender inequality problem (WHO, 2002; WHO, 2005). The negative mental health consequences for assaulted women have been well documented in recent years and show that post-traumatic stress disorder (PTSD), involving symptoms of intrusion, avoidance and hyperarousal (Herman, 2001; Flouri, 2005), and other psychological stress reactions, are long-term mental health consequences of the violence (Scheffer Lindgren and Renck, 2008a; Campbell, 2002; Golding, 1999; Helweg-Larsen and Kruse, 2003; Krantz and Östergren, 2000; Lang, Kennedy and Stein, 2002; Loxton, Schofield and Hussain, 2006; Nixon, Resick and Nishith, 2004; Pico-Alfonso, Garcia-Linares, Celda-Navarro, Blasco-Ros, Eche-Burua and Martinez, 2006; Risberg, Lundgren and Westman, 1999; Romito, Turan and De Marchi, 2005; Schei, Guthrie, Dennerstein and Alford, 2006; Stein and Kennedy 2001; Woods 2005; Zlotnick, Johnson and Kohn, 2006). IPV also has an enormous negative impact on children, either as witnesses to the violence, or as directly abused (Grych, Jouriles, Swank, McDonald and Norwood, 2000; Janson and Almqvist, 2000; Eriksson, 2003; Weinehall, 2005; Wolfe and Jaffe, 1999). Lately the focus has also been on the societal costs of the violence, and these are put at an enormously high figure (National Center for Injury Prevention and Control, 2003; Socialstyrelsen, 2006; Weinehall, Änggård, Blom, Ekelund and Finndal, 2006).

The complexity of a violent relationship and explanations as to why abused women do not leave are described in several studies. Lundgren (1991) explain this in terms of what she calls the normalisation process, a process in which the man constantly controls the woman and minimizes her living space. The phenomenon of traumatic bonding is an important restraining factor in a violent relationship. The women's various feelings are interwoven to create a traumatic bond with the abusers, and thus add to the difficulties in leaving the relationship (Dutton and Painter, 1981). According to Barnett (2001) a multitude of external factors hinder battered women from leaving, for example the shortcomings of the criminal justice system, workplaces, health care practitioners and social service agencies failing to provide the social support needed to leave.

Recently the focus has also been on how and why abused women in fact leave violent relationships. Several studies show that the women are not passive victims but employ various means to solve their situation, for example by leaving (Ellsberg, Winkvist, Pena and Stenlund, 2001; Ruiz-Perez, Mata-Pariente and Plazaola-Castano, 2006). But leaving is for most of the women a long-term process involving several attempts before the definitive break is achieved (Scheffer Lindgren and Renck, 2008b; Barnett, Miller-Perrin and Perrin, 1997; Dobash and Dobash, 1980; Enander, 2008; Walker, 1979).

In recent decades measures have been introduced to improve the situation for victims of crime. In the 1960s victimology was established as a separate branch of criminology. In Sweden the breakthrough came with the debate on rape in the mid 1970s, and a number of new laws have been passed in the field (Lindgren, 2004; Renck, 1997). Until 1982 the women's consent and cooperation was necessary before proceedings could be taken in cases of IPV in Sweden. From 1982 crimes of intimate partner violence have been placed in the domain of public prosecution, which means that legal action can be taken without the women's cooperation (Burman, 2007). The official view thus changed from regarding intimate partner violence as a private matter to considering it a serious crime. The law on restraining orders (SFS 1988:688) was introduced as a part of the Swedish procedural law with the aim of strengthening protection for people suffering from persecution and harassment, with a special focus on cases of intimate partner violence. The law regulates the issuing of contact prohibition orders, which means that a person may not visit or in any other way attempt to make contact with the individual who is under protection (BRÅ, 2003). The Injured party counsel act (SFS 1988:609) was a result of victimology research on so-called secondary victimization, which demonstrated that the situation for an individual who was already victimized could become even worse as a result of the legal process. The law was one facet in the process to improve the situation of crime victims. An injured party counsel is to be appointed early in the process, as soon as the preliminary investigation has taken place. The role of the injured party counsel is to take care of the woman's interests by participating in police interrogations, explaining legal matters, keeping her informed, giving her support through the whole legal process, and also putting forward claims for damages on her behalf (Diesen, 1995; SOU, 2007:6). Through The Swedish protection of women's integrity reform in the 1990s (SOU, 1995:60; Prop, 1997/98:55) the crime of gross violation of a woman's integrity was introduced in the Swedish criminal code (SFS 1962:700) in 1998, and means that a man can be convicted if he commits repeated acts of 
harassment or abuse against a woman with whom he is, or has been, in an intimate relationship, including assault, molestation, violations of the privacy of the home, and sexual coercion. This new regulation was meant to lead to a more stringent sentence than would be the case if each of the acts were considered separately (BR $\AA, 2000)$.

As was shown above, intimate partner violence is very complex and there are several barriers, such as economic, emotional and social-power related factors, for victims of IPV to overcome in order to seek remedies from the criminal justice system and also several factors affecting the victims' behaviour during police investigations and court proceedings (Bui, 2001; Jordan, 2004; Logan, Stevenson, Evans and Leukefeld, 2004; Wolf, Ly, Hobart and Kernic, 2003). To the best of our knowledge, there is a lack of Swedish studies examining the quality of police investigations with a specific focus on IPV. It should be of great importance for abused women when they finally get in contact with legal authorities that criminal justice is achieved, which in this study means safety for female victims and that the laws are applied as they were intended.

\section{Aim of the Study}

The aim of this study was to examine preliminary investigations in Sweden concerning reported crimes of intimate partner violence, to gain knowledge of whether there is criminal justice for female victims of IPV in practice.

The study was designed to address the following questions:

- How prevalent are cases leading to prosecution, and is there a difference between crimes coded as Gross violation of a woman's integrity and other type of crimes?

- Are there any differences in rates of injured party counsels, contact prohibition orders and victim's cooperation in relation to how reported crimes were coded?

- What percentage distribution of background variables and other study variables can be found in relation to prosecution?

- What percentage distribution of prosecution, no interrogation of suspect, detention, contact prohibition order and ongoing relationship can be found in relation to the victim's cooperation?

- What factors predict the prosecution of reported cases?

\section{Sample and Data Collection}

With the intention to answer the questions formulated above the study adopts a quantitative approach, and is part of a larger project. This particular research sample was drawn from all police records of reported cases of men's violence against women in intimate relationships in 2006 in two police departments in Stockholm, Sweden attached to the same public prosecutor's office, $n=474$. About ten per cent of all cases were still pending and not accessible. The total number of cases of IPV reported for all the districts in Stockholm was more than three thousand in 2006 (Diesen, 2008). The police use different crime codes for different kinds of IPV: assault outdoors (0356), assault indoors (0366), gross assault outdoors (0376), gross assault indoors (0386) and gross violation of a woman's integrity (0412). For the purpose of this study the police records contain a certain number of variables which are central and of interest for the legal process, such as type of crime, the ages of the suspect and victim, the nature of the relation, coercive measures taken, frequency of interrogations, if an injured party counsel was provided, if there was a contact prohibition order issued, type of evidence such as witnesses, photos or a legal medical certificate, the woman's willingness to cooperate in the investigation, if the case was dismissed or sent for prosecution, and the time of investigation. In a few cases information is lacking, partly because of incomplete police records. The records were manually investigated, case by case. Because of limited time and financial resources, it was not possible to include more police departments in the study.

Police records are covered by the law governing access to public documents. Thus, in preparation for this study, it was necessary to sign a declaration of secrecy and agree not to reveal the contents of the material or the identity of individuals who were involved in or the subject of the preliminary investigations being studied.

\section{Data Analysis}

The material was processed in different steps, with bivariate and multivariate methods of analysis. To control bivariate relations, the $\chi^{2}$-test was applied (Aronsson, 1999), and to analyse correlations Phi coefficients were computed (Siegel and Castellan, 1988). Multivariate logistic regression analysis was used to construct predictive indices. The dichotomous nature of our variables concerning criminal justice supports the use of logistic regression (Hosmer and Lemeshow, 1989). Prosecution was used as dependent variable. The objectives of the logistic regression analysis were to provide a measure of the relative importance of a number of independent 
variables and to determine which independent variables increased the probability of the crime report leading to prosecution. All analyses were conducted by means of the SPSS statistical program.

\section{Findings}

The age of the women ranged from fifteen to seventy nine, with a mean of 36.3 years $(\mathrm{SD}=11.4)$. The age of the suspects ranged from fifteen to seventy five $(M=39.3, S D=11.2)$. More suspects were of foreign nationality than Swedish, 231 as opposed to 201 (53.5 percent and 46.5 percent respectively). The relationship was in most cases of an ongoing kind (66.2 percent). The mean time for the inquiry was eight weeks (median four weeks), and ranged from one to eighty four weeks. The mean value for the number of interrogations was for the women 1.8 $(\mathrm{SD}=1.5)$ and ranged from 0 to 17 , and for the suspects the mean value was $1.2(\mathrm{SD}=1.4)$ and ranged from zero to sixteen.

\subsection{Bivariate analyses}

The results show that the total number of cases leading to prosecution was 121 (25.5 percent). The majority of reported crimes were coded as assault indoors, 347 cases (73.2 percent), the others as assault outdoors 38 (8.0 percent), as gross assault outdoors and indoors 12 ( 2.5 percent), and 77 reports (16.2 percent) were coded as gross violation of a woman's integrity. The frequency of prosecution within the specific crime codes, gross violation of a woman's integrity, and gross assault indoors, was 46.8 percent respectively to 63.6 percent. The frequency of injured party counsel provisions during the preliminary investigation was in total 87 (18.4 percent), but 34 (44.2 percent) for gross violation of a woman's integrity. For the largest group of crimes, assault indoors, the frequency was 38 (11.0 percent). In 32 (6.8 percent) cases a contact prohibition order was issued, and in 190 (40.1 percent) cases the woman was willing to cooperate in the investigation (Table 1).

Prosecution was analysed in relation to various background and study variables in bivariate analyses (Table 2). No significant relationship was found between prosecution and the woman's age, the relationship to the suspect or if the woman was using drugs/alcohol. In contrast, there was a significant relation between the prevalence of prosecution and whether the suspect was using drugs/alcohol. Prosecution was significantly more prevalent if the suspect was Swedish rather than of foreign nationality (30.8 percent vs. 22.5 percent), if the classification of the crime was gross violation of a woman's integrity versus assault and gross assault (46.8 percent vs. 21.4 percent), if the woman had injured party counsel versus not (74.7 percent vs. 14.5 percent), and whether or not the woman cooperated (51.1 percent vs. 8.5 percent). The relationship between the prevalence of prosecution and whether or not there had been search warrant ( 60.0 percent vs. 21.5 percent), and between prosecution and whether or not the suspect had been served a contact prohibition order (56.3 percent vs. 23.3 percent) was also found to be significant. Further we found a significant relationship between the prevalence of prosecution and whether or not there was access to evidence such as witnesses ( 49.2 percent vs. 8.8 percent), photos (61.7 percent vs. 11.4 percent) and medical legal certificates ( 77.3 percent vs. 15.8 percent). Prosecution was much more prevalent if the suspect had been interrogated (39.5 percent vs. 1.8 percent).

Crosstabulations of the injured party's willingness to cooperate and some of the other variables show that there was a relationship between the woman's willingness to cooperate and the frequency of prosecution. 260 of the cases where the woman was not willing to participate were dismissed (91.5 percent). In 171 cases (36.4 percent) the suspect was not interrogated. There was a relationship between the woman's unwillingness to participate and no interrogation of the suspect. We also found a relationship between the woman's willingness to participate and provision of injured party counsel and a contact prohibition order compared to unwillingness to participate. Finally, the results show a relationship between women not willing to cooperate and the variable ongoing relationship (Table 3).

\subsubsection{Multivariate analysis}

Nine predictor variables were identified for potential inclusion in a logistic regression analysis. As an initial step to check for multicollinearity, Phi correlation coefficients were calculated between each of the nine variables but did not show any high correlations, the highest 0.64 in size. The logistic regression (Table 4) reveals that the variables most likely to increase the probability of the crime report leading to prosecution were whether the suspect had been interrogated and whether the victim was cooperating. In fact, as the odds ratio indicates, the probability of prosecution was about 15 times higher if the suspect had been interrogated (Exp. $(B)=15.708)$, and about 5 times higher if the woman was cooperative (Exp. $(B)=5.195)$ even when other variables were controlled. The following variables also predict whether a crime report will lead to prosecution: whether the victim had an injured party counsel; whether there had been a search warrant, a witness, photos and a medical legal certificate. The suspect's use of drugs was also a significant predictor. On the other hand, the logistic regression reveals that 
a contact prohibition order did not increase the likelihood of prosecution when other factors were taken into consideration.

\section{Discussion and Conclusion}

Our results show that the frequency of cases leading to prosecution was rather high (25.5 percent), at least compared with the frequency in the whole of Stockholm in 2006 (21.4 percent) (Diesen, 2008), and compared with Sweden as a whole (21 percent) in 2007 (BRA, 2008a). If we consider the crime Gross violation of a woman's integrity separately, we see the frequency was even higher compared to the other type of crimes (46.8 percent). The frequency of prosecution of this type of crime has increased a great deal since the new legislation was introduced; at that time it was only 10 percent (BRA, 2000). On the other hand, the variables injured party counsel and contact prohibition order in total show remarkable low scores. Further, taking the separate crime code, gross violation of a woman's integrity, and these two variables, again we find higher scores. This could mean that the introduction of the crime of gross violation of a woman's integrity has, in fact, had an effect. From the reports of the investigations it was quite clear that many of the cases involved different kinds of repeated violence, even cases coded as single violent acts. Coding reported crimes as gross violation of a woman's integrity might more often lead to better quality investigations, a higher number of prosecutions, and a better implementation of the intentions of the laws.

The results show a relationship between different kinds of evidence like witnesses, photos and medical legal certificates and the frequency of cases leading to prosecution, and this is quite logical and not very surprising. The results also show a relationship between drug use in the suspect and cases leading to prosecution. However, it is hard to draw any conclusion regarding whether men using drugs are more violent than others, or whether there is a greater tendency to prosecute this category of men. Prosecution was more prevalent if the suspect was Swedish rather than of foreign nationality and this might suggest an even greater need of support for foreign crime victims through the legal process.

The women showed interest in pursuing prosecution in less than half of the reported crimes. We found a relationship between the injured party's willingness to cooperate and the frequency of cases going to court, which is also shown by the logistic regression analysis. There were a higher number of detention and contact prohibition orders in the group of cooperative victims. We also found a relationship between the victim's unwillingness to cooperate and the variable ongoing relationship. As indicated in the introduction of this article, there are many reasons for abused women not to participate in prosecution. This could mean that the women need to be kept away and protected from the man, either through his detention, a contact prohibition order or separation, to be able and willing to go through the whole legal process. Murray (2008) discusses the frequently posed question of why she does not leave, and turns it around asking why he does not leave, implying that it is important to make it easier for assaulted women to remain safely in their own homes, and for the violent partner to be removed. It is, however, essential to be aware of the fact that the needs of assaulted women are far from uniform and comprehensive and individualized approaches to advocacy are vital, as Allen, Bybee and Sullivan (2004) point out. Further, not only is it important to separate the violent men from the women, but also to provide for an injured party counsel early in the legal process, giving them a prominent role in the preliminary investigation, as is suggested in a Swedish government report (SOU, 2007:6). The women, who are often severely traumatized, need much support to be able to go through with the whole investigation. A Canadian study of battered women's views on the criminal justice system shows, among other things, that it can be trusted and has potential, but that ultimately it disappoints the women in that it cannot protect them and can make matters worse (Barata, 2007).

In our results we found a relationship between the woman's refusal to participate and the lack of interrogation of the suspect. Of course, one reason for dismissing a case when the victim is not willing to cooperate is that there is a lack of other supporting evidence. But interrogating a suspect at least increases the chance of getting some kind of confession, compared with not interrogating him at all. Interrogating a suspect ought to be routine in all kinds of crime, and the fact that interrogation of the suspect is a strong predictor for prosecution, as shown the logistic regression analysis, supports this reasoning.

Given that every woman feels at least some degree of fear and threat when a crime of IPV against her has been reported, a contact prohibition order should be issued in every single case. The law on restraining orders was introduced with a particular focus on restricting IPV, and the issuing of a contact prohibition order is one way of restricting crimes and helping to make the woman feel safer, supported and willing to participate in the investigation. The Swedish National Council for Crime Prevention (BRA, 2003) has evaluated the law on restraining orders and has shown that an approved application for restraining orders was a very positive 
experience for the women since they felt they were trusted. On the other hand, a restraining order only had a deterrent effect on a small group of men who had not previously committed any crime. Restraining orders were issued primarily when there was a clear risk for crime, based on rather subjective judgements, and were rarely used to prevent crime. The women interviewed experienced that there was a lack of information and of continuity, and a failure to respond on the part of the justice system. The Swedish National Counsel for Crime Prevention (BRÅ, 2003) has proposed that police routines on restraining orders be improved, that applications be approved not only in so-called serious cases, and that an overall view of intimate partner violence be adopted.

It is apparent from our data that in many cases the victims made it clear that they did not wish to have an injured party counsel or to have a contact prohibition order issued, which might explain the low scores in our results. Roberts, Wolfer and Mele (2008) discuss the reasons why victims of intimate partner request the withdrawal of protection orders, and the most common reasons were a "concrete change" in the victim or defendant or an emotional attachment to the abuser, in others words similar reasons to those given for not leaving the relationship. On the other hand, receiving a civil protective order may for some women be the impetus they need to separate from a violent partner, whilst for others it is a part of a separation process, as reported by Logan, Walker and Shannon (2008). The majority of the women in that study reported that they felt safer and believed the protective order was effective for 13 months, regardless of the status of the relationship. That means that different kinds of restraining or protective orders both in criminal and civil law may, in fact, be an important tool for women who are trying to end intimate partner violence. It is extremely important to explain to the women what a restraining or protective order means, both legally and practically, and that violations of issued orders should always be reported and consequently investigated. Logan et al. (2008) discuss the need for a better understanding of the factors associated with protective order violations to be able to increase their effectiveness. On the other hand, the logistic regression analysis in our study shows, quite surprisingly, that a contact prohibition order does not increase the likelihood of prosecution when other factors are taken into consideration, and this result should be of interest for further studies.

Intimate partner violence has developed from a private matter into a serious crime, but, as the sample studied suggests, obviously mainly in theory, as Logan, Shannon, Walker and Faragher, (2006) also point out. The words have changed but, as our results show, not the actions. Intimate partner violence has been a public prosecution offence in Sweden since 1982 and this means that legal actions can be taken without the woman's consent or participation. The results of this study show that cases where the women are not willing to cooperate are almost routinely dismissed. The frequency of prosecutions is relatively high, but probably the number of cases resulting in prosecution would probably reach a higher level if the laws really were used as they were intended. In practice, there is obviously still a long way to go before criminal justice has been achieved for abused women in Sweden, at least according to the results of this particular sample from 2006. But the possible generalization of the study results should be considered with caution. First, the study group is limited to two police departments. Second, we cannot be completely sure that the investigation of these cases has produced absolutely correct information. Third the work of the police investigators in the preliminary investigations might contain subjective elements. It is of importance to bear in mind that it is the public prosecutors that are responsible for the preliminary investigations. Even if the police do an excellent job, the results of the investigations are dependent on the judgements and decisions made by the prosecutors. Logan et al. (2006) discuss the ambivalence in public policy about partner violence, the role of the justice system in responding to it and how the justice system seems to mirror the attitudes and values of a broader society that still sees intimate partner violence as a "relationship problem", and not a crime.

In recent decades gender researchers have made gender identity relations visible in the justice system and shown that the judicial discourse to a large extent reflects a stereotypical view on men, women, sexuality and violence (Andersson, 2004; Bui, 2001; Burman, 2007; Crocker, 2005; Erez and King, 2000; Ferraro, 2003, Svensson, 1997). One reflexion on our results is that this could reflect gender relations in some way and we therefore see the need for further studies on the subject. There seems to be a need for more advanced knowledge about gender and the complexity of IPV in relation to the legal system, and even greater willingness to take serious measures against these serious crimes.

\section{References}

Allen, N. E. Bybee, D. I. Sullivan, C. M. (2004). Battered women's multitude of needs. Violence Against Women, 10 (9), 1015-1035. http://dx.doi.org/10.1177/1077801204267658

Andersson, U. (2004). His (word) or hers? A gender theoretical analysis of criminal legal protection against sexual abuse. Doctoral dissertation. Lund: Bokbox. 
Aronsson, A. (1999). SPSS. An introduction to the base module. Lund: Studentlitteratur.

Barata, P. C. (2007). Abused women's perspectives on the criminal justice system's response to domestic Violence. Psychology of Women Quarterly, 31 (2), 202-215. http://dx.doi.org/10.1111/j.1471-6402.2007.00353.x

Barnett, O. W. (2001). Why battered women do not leave, Part 2. Trauma, Violence and Abuse, 2 (1), 3-35. http://dx.doi.org/10.1177/1524838001002001001

Barnett, W., Miller-Perrin, C. L. \& Perrin, R. D. (1997). Family violence across the lifespan. Thousand Oaks: Sage Publications.

BRA (2001). Repeated victimisation (report 2001:3). National council for crime prevention.

BRA (2003). Restraining orders (report 2003:2). Stockholm: National council for crime prevention.

BRA (2008a). National council for crime prevention. [Online] Available: http://www.bra.se/extra/news/?module instance $=1 \&$ id $=274$ (December 6, 2011).

BRA (2008b). National council for crime prevention. [Online] Available: http://www.bra.se/extra/news?module instance $=2 \& i d=37$ (December 6, 2011).

BRA (2000). Gross violation of a woman's integrity (report 2000:11). National council for crime prevention.

Bui, H. N. (2001). Domestic violence victims' behaviour in favour of prosecution: Effects of gender relations. Women \& Criminal Justice, 12 (4), 51-75. http://dx.doi.org/10.1300/J012v12n04_03

Burman, M. (2007.) Criminal law and men's violence against women. Doctoral dissertation. Uppsala: Iustus förlag.

Campbell, J. C. (2002.) Health consequences of intimate partner violence, The Lancet, 359. 1331-1336. http://dx.doi.org/10.1016/S0140-6736(02)08336-8

Crocker, D. (2005). Regulating intimacy. Judicial discourse in cases of wife assault (1970 to 2000). Violence Against Women, 11(2), 197-226. http://dx.doi.org/10.1177/1077801204271837

Diesen, C. (1995). The crime victim and the world around. In Billstrom, M., Bring, C., Diesen, C., Lishajko, M. \& Marmolin, C. Crime victim's right. Stockholm: Juristförlaget.

Diesen, E. (2008). Family violence and abuse - a comparison between the police districts of Stockholm regarding the quality of preliminary investigations. Stockholm University, Institution of law.

Dobash, E. \& Dobash, R. (1980). Violence against wives. London: Open Books.

Dutton, D. \& Painter, S. L. (1981). Traumatic bonding: The development of emotional attachments in battered women and other relationships of intermittent abuse. Victimology: An International Journal, 6, 139-155.

Ellsberg, M. C. Winkvist, A. Pena, R. \& Stenlund, H. (2001). Women's strategic responses to violence in Nicaragua, Journal of Epidemiology and Community Health, 55(8). 547-555. http://dx.doi.org/10.1136/jech.55. 8.547

Enander, V. (2008). Women leaving violent men. Crossroads of emotion, cognition and action. Doctoral dissertation. University of Gothenbourg, Institution of Social work.

Erez, E. King, T. A. (2000). Patriarchal terrorism or common couple violence: Attorney's views of prosecuting and defending woman batterers. Domestic Violence: Global Responses, 207-226. http://dx.doi.org/10.1177/026 975800000700311

Eriksson, M. (2003). In the shadow of daddy - Family law and the handling of fathers' violence. Doctoral dissertation. Stehag: Förlags AB Gondolin.

Ferraro, K. J. (2003). The words change but the melody lingers. Violence against Women, 9(1), 110-129. http://d x.doi.org/10.1177/1077801202238432

Flouri, E. (2005). Post-Traumatic Stress Disorder (PTSD). What we have learned and what we still have not found out. Journal of Interpersonal Violence, 20(4), 373-379. http://dx.doi.org/10.1177/0886260504267549

Golding, J. M. (1999). Intimate partner violence as a risk factor for mental disorders: A meta-analysis. Journal of Family Violence, 14(2), 99-132. http://dx.doi.org/10.1023/A:1022079418229

Grych, J. H., Jouriles, E. N., Swank, P. R., McDonald, R. \& Norwood, W. D. (2000). Patterns of adjustment among children of battered women. Journal of Consulting \& Clinical Psychology, 68(1), 84-94. http://dx.doi.org /10.1037//0022-006X.68.1.84 
Helweg-Larsen, K. \& Kruse, M. (2003). Violence against women and consequent health problems: a register-based study. Scandinavian Journal of Public Health, 31(1), 51-57. http://dx.doi.org/10.1080/140349402 10133708

Herman, J. L. (2001). Trauma and recovery. From domestic abuse to political terror. London: Pandora.

Hosmer, D. W. \& Lemeshow, S. (1989). Applied logistic regression. New York: John Wiley \& Sons.

Janson, S. \& Almqvist, K. (2000). Children witnessing violence. Läkartidningen, 97(38), 4094-4099.

Jordan, C. E. (2004). Intimate partner violence and the justice system. An examination of the interface. Journal of Interpersonal Violence, 19(12), 1412-1434. http://dx.doi.org/10.1177/0886260504269697

Krantz, G. \& Östergren, P. O. (2000). The association between violence victimisation and common symptoms in Swedish women. Journal of Epidemiology and Community Health, 54(11), 815-821. http://dx.doi.org/10.1136/ jech.54.11.815

Lang, A. J. \& Kennedy, C. M. Stein, M. B. (2002). Anxiety sensitivity and PTSD among female victims of intimate partner violence. Depression and Anxiety, 16(2), 77-83. http://dx.doi.org/10-1002/jts.20457

Laycock, G. (1997). Intimate partner violence. Repeated victmization - preventive strategies. In Olsson, M. (Eds.). Violence against women. Stockholm: Fritzes.

Lindgren, M. (2004). Crime victims in the criminal justice process - on ideal victims and good authorities. Doctoral dissertation. Stockholm: Jure.

Logan, T. K. Shannon, L. Walker, R. \& Faragher, T. M. (2006). Protective orders. Questions and conundrums. Trauma, Violence, \& Abuse, 7(3), 175-205. http://dx.doi.org/10.1177/1524838006288930

Logan, T. K. Stevenson, E. Evans, L. \& Leukefeld, C. (2004). Rural and urban women's perceptions of barriers to health, mental health, and criminal justice services: implications for victim services. Violence \& Victims, 19(1), 37- 62. http://dx.doi.org/10.1891/vivi.19.1.37.33234

Logan, T. K. Walker, R. \& Shannon, L. (2008). Factors associated with separation and ongoing violence among women with civil protective orders. Journal of Family Violence, 23(5), 377-385. http://dx.doi.org/10.1177/0886 260508317186

Loxton, D., Schofield, M. \& Hussain, R. (2006). Psychological health in midlife among women who have ever lived with a violent partner or spouse. Journal of Interpersonal Violence, 21(8), 1092-1107. http://dx.doi.org/10. $1177 / 0886260506290290$

Lundgren, E. (1991). The normalisation process of violence - Two parties -Two strategies. Stockholm: ROKS.

Lundgren, E., Heimer, G.,Westerstrand, J. \& Kalliokoski, A. M. (2001). Captured Queen', Men's violence against women in 'equal' Sweden - a prevalence study. Stockholm: Crime victim compensation and support authority.

Mendelsohn, B. (1963). The origin of the doctrine of victimology. Exerpta Criminologica, 3(30), 239-244.

Murray, S. (2008). Why doesn't she just leave?: Belonging, disruption and domestic Violence. Women's Studies International Forum, 31(1), 65-72. http://dx.doi.org/10.1016/j.wsif.2007.11.008

National Center for Injury Prevention and Control (2003). Costs of Intimate Partner Violence against Women in the United States. Atlanta, GA: Centers for Disease Control and Prevention.

Nixon, R. D. V., Resick, P. A. \& Nishith, P. (2004). An exploration of comorbid depression among female victims of intimate partner violence with posttraumatic stress disorder. Journal of Affective Disorders, 82(2), 315-320. http://dx.doi.org/10.1016/j.jad.2004.01.008

Pico-Alfonso, M. A., Garcia-Linares, M. I., Celda-Navarro, N., Blasco-Ros, C., Echeburua, E. \& Martinez, M. (2006). The impact of physical, psychological, and sexual intimate male partner violence on women's mental health: Depressive symptoms, posttraumatic stress disorder state anxiety, and suicide. Journal of Women's Health, 15(5), 599-611. http://dx.doi.org/10.1089/jwh.2006.15.599

Proposition .Government bill. 1997/98:55. Womens integrity. Stockholm: Swedish government.

Renck, B. (1997). Victims of Crime in a Public Health Perspective: Some Typologies and Tentative Explanatory Models. Doctoral dissertation. Gothenburg: NHV. 
Risberg, G., Lundgren, E. \& Westman, G. (1999). Prevalence of sexualized violence among women. A population-based study in a primary healthcare district. Scandinavian Journal of Public Health, 27(14), $247-253$. http://dx.doi.org/10.1177/14034948990270040801

Roberts, J. C., Wolfer, L. \& Mele, M. (2008). Why victims of intimate partner violence withdraw protection orders. Journal of Family Violence, 23(5), 369-375. http://dx.doi.org/10.1007/s10896-008-9161-z

Romito, P., Turan, J. M. \& De Marchi, M. (2005). The impact of current and past interpersonal violence on women's mental health. Social Science \& Medicine, 60(8), 1717-1727. http://dx.doi.org/10.1016/j.socscimed.20 04.08 .026

Ruiz-Perez, I., Mata-Pariente, N. \& Plazaola-Castano, J. (2006). Women's response to intimate partner violence. Journal of Interpersonal Violence, 21(9), 1156-1168. http://dx.doi.org/10:177/0886260506290421

Scheffer, L. M. \& Renck, B. (2008a). It is still so deep-seated, the fear": psychological stress reactions as consequences of intimate partner violence. Journal of Psychiatric and Mental Health Nursing, 15, $219-228$. http://dx.doi.org/10.1111/j.1365-2850.2007.01215x

Scheffer, L. M. \& Renck, B. (2008b). Intimate partner violence and the leaving process: Interviews with abused women. International Journal of Qualitative Studies on Health and Well-being, 3, 113-124. http://dx.doi.org/10. 1080/17482620801945805

Schei, B., Guthrie, J. R., Dennerstein, L. \& Alford, S. (2006). Intimate partner violence and health outcomes in mid-life women: a population cohort study. Archives of women's mental health, 9(6), 317-324. http://dx.doi.org/ 10.1007/s00737-006-0156-6

SFS 1962:700. Swedish Criminal Code. Stockholm: Swedish government.

SFS 1988:609. Injured party counsel act. Stockholm: Swedish government.

SFS 1988:688. Law on restraining orders. Stockholm: Swedish government.

Siegel, S. \& Castellan, J. (1988). Nonparametric statistics for the behavioral sciences. Singapore: McGraw-Hill Book Co.

The National board of health and welfare (2006). Costs of violence against women - a socio-economic analysis. Stockholm. The National board of health and welfare.

SOU 1995:60. Women's integrity. Swedish government official reports. Stockholm: Fritzes.

SOU 2007:6. The Injured party counsel- an active support in the legal process. Swedish government official reports. Stockholm: Fritzes.

Stein, M. B. \& Kennedy, C. (2001). Major depressive and post-traumatic stress disorder comorbidity in female victims of intimate partner violence. Journal of Affective Disorders, 66(2-3), 133-138. http://dx.doi.org/10.1016/ S0165-0327(00)00301-3

Svensson, E. M. (1997). Gender and law -Problemizing the concept of law. Doctoral dissertation, Uppsala: Iustus förlag.

Tjaden, P. \& Thoennes, N. (2000). Full Report of the Prevalence, Incidence, and Consequences of Violence against Women: Findings from the National Violence Against Women Survey. Washington, DC: National Institute of Justice.

Walker, L. (1979). The Battered Woman. New York: Harper Colophon Books.

Watts, C. \& Zimmerman, C. (2002). Violence against women: global scope and magnitude. The Lancet, 359 (9313), 1232-1237. http://dx.doi.org/10-1016/S0140-6736(02)08221-1

Weinehall, K. (2005). Take my father away from home: children growing up in the proximity of violence. In Eriksson, M., Hester, M., Keskinen, S. \& Pringle, K. (Eds.). Tackling Men's Violence in Families. Nordic Issues and Dilemmas. Bristol: The Policy Press.

Weinehall, K., Anggard, A., Blom, K., Ekelund, B. \& Finndal, K. (2006). Count on costs - a case study on men's biolence against women. University of Umea, Department of Law.

WHO, (2002). World Report on Violence and Health. Geneva: World Health Organisation.

WHO, (2005). WHO Multi Country Study on Women's Health and Domestic Violence against Women. Geneva: World Health Organisation. 
Wolf, M., Ly, U., Hobart, M. \& Kernic, M. (2003). Barriers to seeking police help for intimate partner violence. Journal of Family Violence, 18(2), 121-129. http://dx.doi.org/10.1023/A:1022893231951

Wolfe, D. A. \& Jaffe, P. G. (1999). Emerging strategies in the prevention of domestic Violence. The Future of Children, 9(3), 133-144.

Woods, S. J. (2005). Intimate partner violence and post-traumatic stress disorder symptoms in women. What we know and need to know. Journal of Interpersonal Violence, 4(20), 394-402. http://dx.doi.org/10.1177/088626 0504267882

Zlotnick, C., Johnson, D. M. \& Kohn, R. (2006). Intimate partner violence and long-term psychosocial functioning in a national sample of American women. Journal of Interpersonal Violence, 21(2), 262-275. http://d x.doi.org/10.1177/0886260505282564

Table 1. Frequency and percentage of prosecution, injured party counsel, contact prohibition order, the victim's cooperation in preliminary investigations, in relation to type of crime and reported cases of IPV $(n=474)$

\begin{tabular}{|c|c|c|c|c|c|c|c|c|c|}
\hline & & \multicolumn{2}{|c|}{ Prosecution } & \multicolumn{2}{|c|}{ Injured party counsel } & \multicolumn{2}{|c|}{ Contact prohibition order } & \multicolumn{2}{|c|}{ Victim's cooperation } \\
\hline \multicolumn{2}{|c|}{ Crime code* (n) } & (n) & $(\%)$ & (n) & $(\%)$ & (n) & $(\%)$ & (n) & $(\%)$ \\
\hline 0356 & $(38)$ & 17 & 44.7 & 9 & 23.7 & 0 & 0.0 & 21 & 55.3 \\
\hline 0366 & $(347)$ & 60 & 17.3 & 38 & 11.0 & 15 & 4.3 & 114 & 32.9 \\
\hline 0376 & (1) & 1 & 100.0 & 0 & 0.0 & 0 & 0.0 & 1 & 100.0 \\
\hline 0386 & (11) & 7 & .6 & 6 & 54.5 & 1 & 9.1 & 8 & 72.7 \\
\hline 0412 & $(77)$ & 36 & 46.8 & 34 & 44.2 & 16 & 20.8 & 46 & 59.7 \\
\hline Total & $(474)$ & 121 & 25.5 & 87 & 18.4 & 32 & 6.8 & 190 & 40.1 \\
\hline
\end{tabular}

*Crime codes: assault outdoors (0356), assault indoors (0366), gross assault outdoors (0376), gross assault indoors (0386) and gross violation of a woman's integrity (0412). 
Table 2. Bivariate percentage distribution - background variables and other study variables in relation to prosecution

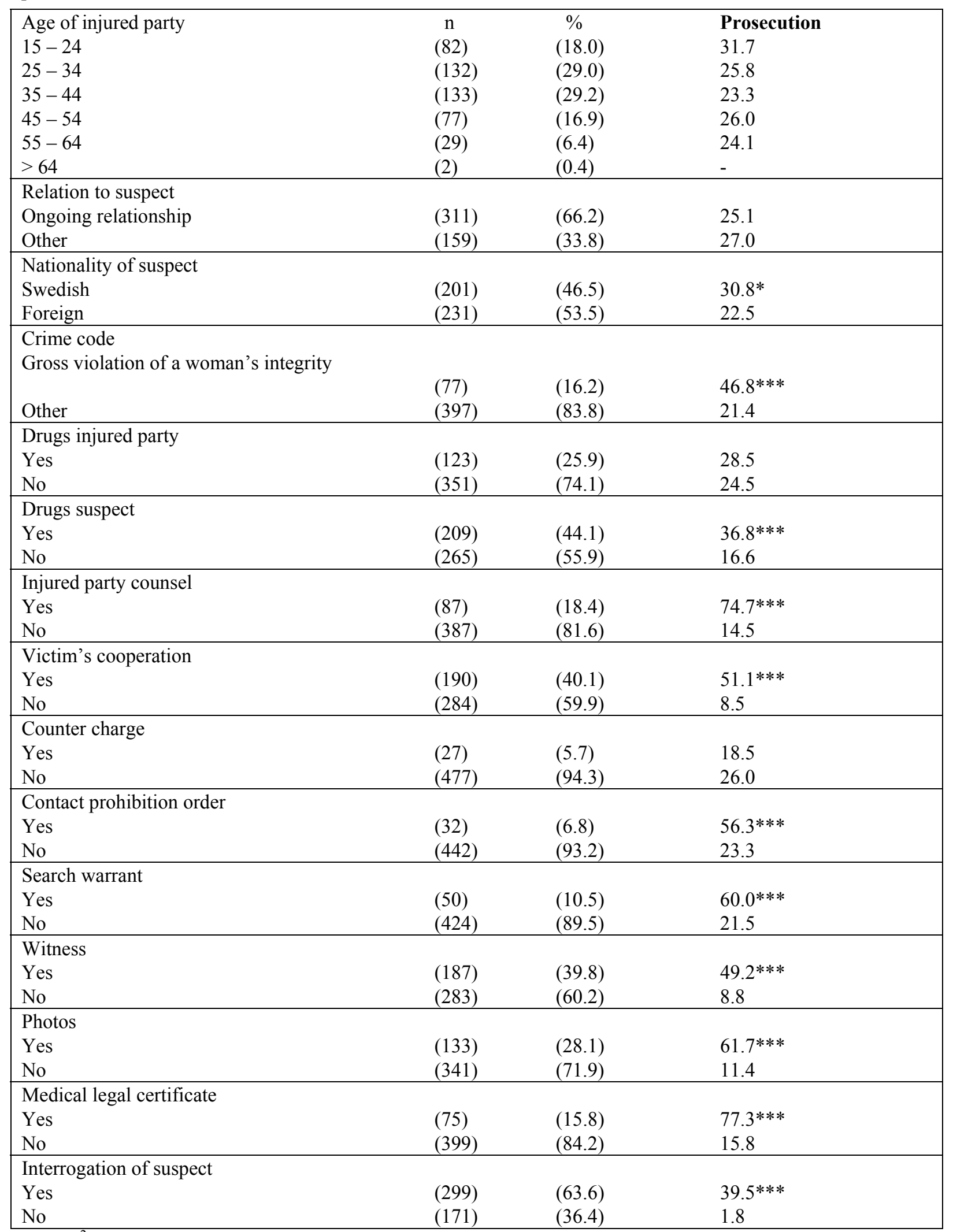

Note: $\chi^{2}$ - test

$* \mathrm{p}<.05, * * \mathrm{p}<.01, * * * \mathrm{p}<.001$ 
Table 3. Victim's cooperation in preliminary investigations, in relation to frequency of prosecution, detention of suspect, interrogation of suspect, contact prohibition order, injured party counsel and ongoing relationship $(\mathrm{n}=474)$

\begin{tabular}{|c|c|c|c|c|c|c|c|c|c|c|c|c|}
\hline & \multicolumn{2}{|c|}{ Prosecution } & \multicolumn{2}{|c|}{ Detention } & \multicolumn{2}{|c|}{$\begin{array}{l}\text { No } \\
\text { interrogation } \\
\text { of suspect }\end{array}$} & \multicolumn{2}{|c|}{$\begin{array}{l}\text { Contact } \\
\text { prohibition } \\
\text { order }\end{array}$} & \multicolumn{2}{|l|}{$\begin{array}{l}\text { Injured } \\
\text { Party } \\
\text { counsel }\end{array}$} & \multicolumn{2}{|c|}{$\begin{array}{l}\text { Ongoing } \\
\text { relation- } \\
\text { ship }\end{array}$} \\
\hline $\begin{array}{l}\text { Victim's } \\
\text { cooperation } \\
\text { (n) }\end{array}$ & (n) & $(\%)$ & (n) & $(\%)$ & (n) & $(\%)$ & (n) & $(\%)$ & (n) & $(\%)$ & (n) & $(\%)$ \\
\hline Yes (190) & 97 & 51.1 & 29 & 15.3 & 37 & 19.7 & 22 & 11.6 & 66 & 34.7 & 111 & 58.7 \\
\hline No $\quad(284)$ & 24 & 8.5 & 8 & 2.8 & 134 & 47.5 & 10 & 3.5 & 21 & 7.4 & 200 & 71.2 \\
\hline Tot (474) & 121 & 25.5 & 37 & 7.8 & 171 & 36.4 & 32 & 6.8 & 87 & 18.4 & 311 & 66.2 \\
\hline
\end{tabular}

Table 4. Logistic Regression Analysis: Factors predicting the prosecution

\begin{tabular}{|lllll|}
\hline Independent variable & $\mathrm{B}$ & $\mathrm{SE}$ & Exp. (B) & $95 \% \mathrm{CI}$ \\
\hline Injured party counsel & 1.270 & .399 & $3.560^{* *}$ & $1.630-7.779$ \\
Victim's cooperation & 1.648 & .339 & $5.195^{* * *}$ & $2.674-10.090$ \\
Contact prohibition order & .064 & .577 & 1.066 & $.344-3.299$ \\
Search warrant & .982 & .475 & $2.669^{*}$ & $1.052-6.775$ \\
Witness & 1.354 & .353 & $3.872^{* * *}$ & $1.938-7.736$ \\
Photos & .788 & .390 & $2.198^{*}$ & $1.024-4.722$ \\
Medical legal certificate & 1.247 & .460 & $3.480^{* *}$ & $1.411-8.580$ \\
Drugs suspect & .690 & .333 & $1.994^{*}$ & $1.038-3.830$ \\
Interrogation of suspect & 2.754 & .694 & $15.708^{* * *}$ & $4.028-61.259$ \\
Constant & -6.461 & .810 & - & - \\
\hline
\end{tabular}

Note: $* \mathrm{p}<.05, * * \mathrm{p}<.01, * * * \mathrm{p}<.001$

Nagelkerke R Square $=.667$ 